\title{
FBI encourages librarians to be on the look out for spies
}

\section{Washington}

MucH to the disappointment of libraries around the United States, the Federal Bureau of Investigation (FBI) will continue its controversial Library Awareness Program which seeks the assistance of library workers in identifying foreign spies using libraries.

The FBI programme became a national issue last year following an agent's visit to a Columbia University library. The FBI programme involves certain scientific and technical libraries (including university and public libraries) in the New York City area, and is an attempt to inform librarians of "intelligence-gathering activities that may be harmful to the United States", and to enlist librarians' help in identifying those activities.

The FBI focused on New York because of the large number of foreign missions located there. Library visits in other parts of the country, the FBI maintains, were connected with specific investigations.

But librarians have argued that the programme as initially conceived was far too vague. How, they asked, were they to determine which "intelligence gathering" was harmful? And how was it possible to identify library users as Soviet or Sovietbloc nationals? Was a foreign-sounding name a sufficient criterion?

The FBI's request also raised the question of confidentiality of library records. Thirty-eight states now have library confidentiality laws, and libraries tend to look askance at steps that might curtail users' access to information in the library, a right protected by the first amendment of the US Constitution which guarantees freedom of speech.

Representative Don Edwards (Democrat, California), chair of the civil and constitutional rights subcommittee, held hearings earlier this year on the FBI's activities. Following the hearing, FBI director William Sessions wrote to Edwards, outlining more specific guidelines on how the programme would function. Librarians will be told to look out for

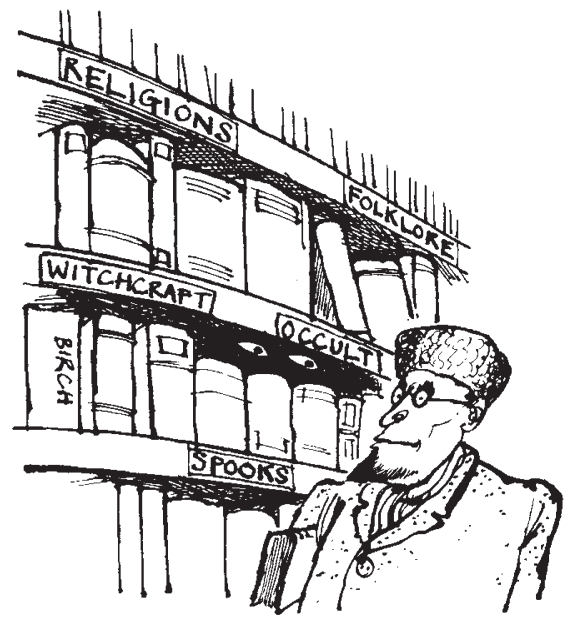

individuals who identify themselves as Soviet or Soviet-bloc nationals and seek assistance in conducting library research, request referrals to students or faculty who might assist in research projects, remove library materials without permission, or "seek certain biographical or personality assessment information from librarians themselves and/or on individuals who are known to the librarian being queried, particularly on students and academicians".

\section{University problems with database users}

\section{Berkeley}

UNIVERSITIES may have to worry about keeping an eye on their database users. Some databases come with a restriction that bars access to non-US citizens. But librarians remain unclear over the extent of their legal liabilities.

The problem attracted notice last spring when Gary Lawrence, University of California coordinator of library affairs, directed librarians throughout the university to stop using the National Aeronautics and Space Adminstration (NASA)'s RECON aerospace database after discovering that the use agreement barred foreign citizens from access to it. He advised libraries to switch to the Dialog database which includes much of the same material as RECON, and costs more, but has no citizenship requirement.

But John Wilson, manager of database products for NASA, says the US citizenship clause in the RECON agreement is misleading. The true intent is that the information - which is subject to the Export Control Act for purposes of maintaining US technological superiority - should not be exported to foreign governments or companies. Restrictions on the use of citations and abstracts are the same, says Wilson, whether they are retrieved through RECON or through Dialog. He says that in neither case is US citizenship a requirement for access, as long as the information will be used in the United States, for research or educational purposes.

That explanation does not convince Lawrence. He maintains that by signing the agreement, with its citizenship requirement clause, the university would expose itself to legal liability should a non-US citizen violate the export restrictions.

Marcia Barinaga
Software exports

Bangalore

THE government of India is to launch a package of incentives designed to boost the export of computer software. Most conspicuous is the provision of duty concessions on computer hardware imported for the development of software. The Department of Electronics is to complete technology parks at Bhubaneshwar, Bangalore, Chandigarh and Pune geared to the export of software.

Dedicated satellite channels will be provided for computer links with Western countries. Indian software exports, mainly to the United States, are currently worth Rs800 million and are expected to be worth as much as Rs3,000 million by the end of the decade.

The software trade is controversial because US engineers protest that they are losing jobs to India, and Indian engineers protest that they are much less well paid than their US rivals. Radhakrishna Rao

Sessions promised that the FBI would not ask for information about people with "foreign-sounding names or accents", or for reports of "suspicious" or "anomalous" behaviour. In his letter, Sessions also said that if librarians do not wish to help the FBI in this effort, "that is up to them".

James Schmidt, chair of the American Library Association's Intellectual Freedom Committee, in a letter earlier this month to Edwards, agrees that Sessions has narrowed the scope of the programme, but believes that the FBI still does not understand that "however important [the FBI's] duties may be, they are subordinate to the first amendment rights of patrons lawfully using a library, and to state confidentiality laws".

A congressional attempt to enact federal confidentiality laws protecting library users was made this year, but withered under a blistering attack from the FBI. The protections were to be added to the Video Rental Privacy Protection Act (now law) that protects video store rental records. The act resulted from outrage over an article in a Washington tabloid describing the movies that Supreme Court nominee Robert Bork had rented. The article appeared while the Senate was considering the Bork nomination.

When Congress attempted to protect library records as well - using the logic that it was perverse to protect those who wanted to watch War and Peace, but not those who wanted to read it - the FBI objected. It insisted that a clause be added giving it access to library records under the aegis of a national security letter, an instrument that requires no judicial supervision. Threatened with this, library groups withdrew support for the bill, opting for the status quo. Joseph Palca 